1 Evidence for cavity-dwelling microbial life in 3.22 Ga-old tidal deposits

2 Martin Homann ${ }^{1}$, Christoph Heubeck ${ }^{2}$, Tomaso R.R. Bontognali ${ }^{3}$ and Alessandro Airo ${ }^{1}$

$3{ }^{1}$ Institute of Geological Sciences, Freie Universität Berlin, Malteserstr. 74-100, 12249 Berlin,

4 Germany

$5 \quad{ }^{2}$ Department of Geosciences, Friedrich-Schiller-Universität Jena, Burgweg 11, 07749 Jena,

$6 \quad$ Germany

$7 \quad{ }^{3}$ ETH Zurich, Geological Institute and Institute of Geochemistry and Petrology, Sonneggstr. 5, $8 \quad 8092$ Zurich, Switzerland

10 ABSTRACT

11 Cavities are considered as plausible and favorable habitats for life on early Earth. In such 12 microenvironments, organisms may have found an adequate protection against the intense 13 ultraviolet (UV) radiation that characterized the Archean ozone-free atmosphere. However, while

14 there is clear evidence that benthic life existed in the Paleoarchean, the oldest traces of cavity-

15 dwelling microbes (coelobionts) have been found thus far in Neoarchean rocks. Here we present

16 the results of a detailed investigation of early-silicified cavities occurring in the oldest well-

17 preserved siliciclastic tidal deposits, the 3.22 Ga-old Moodies Group of the Barberton Greenstone

18 Belt (South Africa). Downward-growing microstromatolitic columns, comprised of kerogenous

19 laminae, are commonly present in planar, bedding-parallel, now silica-filled cavities that formed

20 in sediments of the peritidal zone. In-situ $\delta^{13} \mathrm{C}_{\mathrm{PDB}}$ measurements of the kerogen range from $-32.3 \%$

21 to $-21.3 \%$ and are consistent with a biogenic origin. Scanning electron microscopy (SEM) analysis

22 of the silicified cavities show well-preserved chains of cell-sized molds that we interpret as fossil

23 filamentous microorganisms. The geological context, the morphology of the microstromatolites,

24 the $\delta^{13} \mathrm{C}$ composition of the kerogen, and the presence of microfossils all suggest that a microbial 
25 community inhabited the cavities. Our results extend the geological record of coelobionts by $\sim 0.5$

$26 \mathrm{Ga}$, supporting the view that cavities were among the first ecological niches to have been occupied

27 by early microorganisms.

29 INTRODUCTION

30 Stromatolites interpreted as fossil microbial mats, permineralized microfossils in chert, and

31 kerogen with characteristic carbon isotopic signatures all suggest that microbial life was

32 widespread in the photic zone of Paleoarchean coastal environments (Nisbet and Sleep, 2001;

33 Altermann and Kazmierczak, 2003; Brasier et al., 2006; Schopf, 2011; Bontognali et al., 2012).

34 However, due to the absence of an ozone shield, the high surface UV-flux in that period was

35 presumably harsh to lethal for unprotected microorganisms within minutes to days (Cockell, 2000;

36 Cockell and Raven, 2007). Under such unfavorable conditions, early microbial communities

37 thriving in the photic zone supposedly employed one or several protective mechanisms, e.g., high

38 DNA repair capability, biosynthesis of pigments, radiation screening by mineral incrustation or by

39 matting, the accumulation of surficial dead biomass (Garcia-Pichel and Bebout, 1996; Cockell,

40 1998; Phoenix et al., 2001). Furthermore, organisms can actively migrate to and colonize UV-

41 protected subsurface habitats within the sediment (endobenthic; Noffke, 2010), within solid rocks

42 (endolithic; Walker et al., 2005; Walker and Pace, 2007) or in cavities (coelobiontic; Kobluk and

43 James, 1979; Phoenix et al., 2006). Unambiguous evidence for those strategies, however, is hard

44 to find in the fossil record; currently, the oldest remnants of cavity-dwelling microbial communities

45 have been identified in 2.75 Ga-old fluvio-lacustrine sediments of the Fortescue Group, Australia

46 (Rasmussen et al., 2009). We here present remarkably well-preserved remains of a 3.22 Ga-old

47 microbial community that colonized subsurface cavities beneath microbial mats in tidal sands of 48 the Barberton Greenstone Belt (BGB), South Africa. 


\section{GEOLOGICAL AND PALEOENVIRONMENTAL SETTING}

51 The Moodies Group ( 3.22 Ga), uppermost unit of the BGB (ca. 3.57-3.22 Ga), comprises mainly

52 fine- to coarse-grained, quartz-rich sandstones and subordinate conglomerates, siltstones, and thin

53 volcanic tuffs deposited in tidal and deltaic settings (Anhaeusser, 1976; Eriksson, 1978; Eriksson,

54 1979; Heubeck and Lowe, 1994; Heubeck and Lowe, 1999; Heubeck et al., 2013). Moodies strata

55 are particularly well preserved on the $\sim 3-\mathrm{km}$-thick overturned limb of the Saddleback Syncline in

56 the central BGB north of the Inyoka Fault where they have undergone only lower-greenschist-

57 facies metamorphism (Toulkeridis et al., 1998). The lower part of this succession (unit MdQ1 of

58 Anhaeusser, 1976), approx. $1 \mathrm{~km}$ thick, contains the world's oldest known record of macroscopic

59 microbial mats in a siliciclastic tidal setting, laterally traceable for about 15 kilometers (Noffke et

60 al., 2006; Heubeck, 2009; Homann et al., 2015). The mats, preserved as kerogen-rich laminae,

61 developed distinct morphological adaptations to coastal floodplain, supra-, and intertidal

62 conditions and were likely formed by phototrophic microbial communities (Homann et al., 2015).

63 They are commonly underlain by chert lenses, which we interpret as former cavities beneath

64 unconsolidated but microbially-bound cohesive sediment (Fig 1A). In the studied unit of the

65 Moodies Group these bedding-parallel chert-filled cavities are restricted to tidal-facies, fine- to

66 coarse-grained sandstones and contain kerogenous microstructures described below.

68 SAMPLES AND METHODS

69 Outcrop samples were slabbed, polished and thin-sectioned. For scanning electron microscopy

70 (SEM), only fresh chert samples without weathered surfaces or fractures were selected in order to

71 avoid contamination. Samples were mechanically broken, cleaned in an ultrasonic bath and

72 immediately dried and gold-coated. Sample analysis was performed at the Freie Universität Berlin 
73 using a ZEISS SUPRA 40 VP SEM operating with $20 \mathrm{kV}$ acceleration voltage. In situ carbon

74 isotope analyses of silicified kerogen were performed with a CAMECA IMS 1280 at the Swiss

75 SIMS facility located at the University of Lausanne, Switzerland.

RESULTS

\section{Cavities and associated kerogenous microstructures}

79 The lens-shaped, laterally-tapering cavities are up to $10 \mathrm{~s}$ of $\mathrm{cm}$ in width and less than $0.5 \mathrm{~cm}$ in

80 height. They typically occur below a $<3 \mathrm{~mm}$ thin sandstone layer, which is overlain by a fossil

81 microbial mat (Fig. 1B). Cavity ceilings are commonly coated by dark, kerogenous laminae with

82 downward-facing protrusions and pendant columns that are up to $1.5 \mathrm{~mm}$ in length and $0.6 \mathrm{~mm}$

83 wide (Fig. 2A). Well-preserved single or coalescing columns contain multiple, closely spaced, 1-5

$84 \mu \mathrm{m}$ thick, subparallel stromatolitic laminae of kerogenous composition that are oriented convex-

85 down and taper toward the margins of the columns (Figs. 2B and 2C). Occasionally, the columns

86 terminate in a prominent, up to $30 \mu \mathrm{m}$-thick lamina (Fig. 2C). Remnants of zoned ferroan dolomite

87 rhombs, $10-100 \mu \mathrm{m}$ in diameter, occur scattered throughout the cavity-filling chert and are

88 particularly abundant in the tips of some columns (Figs. 2D-F). The dark kerogenous laminae are

89 commonly encrusted by light-colored silicified cements that are $100-400 \mu \mathrm{m}$ thick and widely

90 discontinuous. In some places, these cement crusts are botryoidal and contain bladed to acicular

91 ghost crystals resembling aragonite (Fig. 2G and 2H; Grotzinger and Reed, 1983). In other places,

92 laminae are disrupted and bent upwards (Fig. 2H) or occur as detached, slightly deformed

93 fragments near the cavity floor (Fig. 2I). 
98 SEM images of the cavity-filling chert show a meshwork of interwoven filamentous molds that is

99 completely embedded in the chert (Fig. 3A). These thread-like, non-bifurcating filamentous

100 microstructures are $0.3-0.5 \mu \mathrm{m}$ in diameter $(\mathrm{n}=180)$ and reach several $10 \mathrm{~s}$ of $\mu \mathrm{m}$ in length. They

101 are commonly bent with abundant changes in orientation; in places, they show a subdivision in

102 regularly-spaced, $\sim 2 \mu \mathrm{m}$-long, rod-shaped segments (Figs. 3B-D). Individual segments are about

103 five-times longer than wide and have rounded ends. Transverse cross-sections through filamentous

104 structures show that they are cylindrical, hollow and encased by a $\sim 100 \mathrm{~nm}$-thick silica layer (Figs.

105 3D-F).

106

\section{Carbon isotope data}

108 In-situ measured $\delta^{13} \mathrm{C}_{\mathrm{PDB}}$ (Peedee belemnite) values from the kerogenous laminae within the

109 cavities vary between $-32.3 \%$ and $-21.3 \%$ with a mean value of $-26.5 \%$ ( $n=12$; Figs. 4A and 4B),

110 which is consistent with a biotic origin of the kerogen (Schidlowski, 2001). Bulk $\delta^{13} \mathrm{C}_{\mathrm{PDB}}$

111 measurements of extracted kerogenous material from the mats above the cavities show a similar

112 range of values (i.e., between $-33.2 \%$ and $-21.9 \%$ ) with a slightly more negative mean value of -

$11329.5 \%$ o $(n=6)$. Poorly preserved dolomite crystals within the chert yield mean values of $-0.3 \%$

$114 \delta^{13} \mathrm{C}_{\mathrm{PDB}}$ and $-14.9 \% \delta^{18} \mathrm{OPDB}(\mathrm{n}=6)$ that are common values for dolomitic carbonates of Archean

115 age (Schidlowski et al., 1975; Shields and Veizer, 2002; Grossman, 2012)

\section{DISCUSSION}

118 The shape and size of the observed cavities resemble gas-filled, fenestral hollows in modern tidal

119 environments that widely occur near the sediment-water interface a few millimeters to centimeters

120 beneath cohesive, impermeable microbial mats and mat-bound sediments (Gerdes et al., 2000; 
121 Schieber et al., 2007). Such cavities form either through accumulation of gases produced by

122 metabolic activity (e.g. $\mathrm{O}_{2}, \mathrm{CO}_{2}, \mathrm{CH}_{4}$ ) or simply by tidal-driven hydraulic pumping of the ambient

123 air trapped in pore space.

124 The in situ formation of the kerogenous lamina with common columnar microstromatolitic 125 structures at the cavity ceiling is evidenced by their downward accretionary growth habit. This 126 particular geometry is well-known from cavity-dwelling microorganisms attached to the roof of 127 cryptic voids, e.g., in Paleo- and Mesozoic reefal limestones (Kobluk and James, 1979; Olivier et 128 al., 2003; Jakubowicz et al., 2014) and has also been observed in modern sea caves that are 129 encrusted by pendant microbialites (Léveillé et al., 2000). Hence, we conclude that the 130 microstromatolitic structures found in the cavities of the Moodies Group were built by a 131 coelobiontic community distinct from those of the overlying epibenthic microbial mats.

132 The carbonate cement fans alternating with the kerogenous laminae built by coelobionts likely 133 formed through abiogenetic encrustation (Riding, 2008) during periods of partial or complete 134 desiccation, a common feature in tidal environments. Subsequently, early silicification replaced 135 large parts of the carbonates and prevented the destruction of the cavities while promoting the 136 preservation of the biological components (Bartley, 1996).

137 The biogenic origin of the observed filaments is supported by the following attributes: (1) tubular 138 morphology with constant diameter; (2) regular segmentation; (3) hollow interior; (4) colonial 139 occurrence; and (5) curved appearance indicating a former flexibility (Schopf, 2004). The 140 morphology of the filaments with respect to their size, shape, and cell-like segmentation is 141 strikingly similar to that of modern filamentous microorganisms (Boone et al., 2001), such as some 142 chemotrophic (e.g., methanogens) and phototrophic bacteria (e.g., non-sulfur and cyanobacteria), 143 which are known to be well preserved in modern siliceous stromatolites and other settings (Jones 144 et al., 2005). Similar filamentous structures have been identified as former microorganisms in 
145 chert-filled cavities from 1.2 Ga-old paleokarst deposits (Horodyski and Knauth, 1994) and in

146 various shallow-marine cherts of Archean age (Schopf, 2006; Westall et al., 2006; Sugitani et al., 147 2013).

148 The radiation-screening effect of epibenthic microbial mats creates UV-protected subsurface 149 habitats a few millimeters beneath the mat. (Garcia-Pichel and Bebout, 1996; Jackson, 2014). The

150 supposedly high Archean UV flux reaching the surface would have made such niches even more

151 favorable for microorganisms (Cockell, 1998). A modern analog environment with increased solar

152 radiation is found in Chilean high-altitude hot-spring sinters where photosynthetic communities

153 thrive in UV-protected voids 1-10 mm below the siliceous sinter surface (Phoenix et al., 2006). If

154 the photosynthetically active radiation penetrating into the cavities described in this study was not

155 sufficient for photosynthesis it can be assumed that the microbial communities were dominated by

156 chemotrophic organisms. Rasmussen et al. (2009) reported geochemical evidence for the presence

157 of chemotrophic coelobionts preserved as columnar microstructures in synsedimentary cavities of

158 the Neoarchean Fortescue Group (Australia). They interpreted the negative $\delta^{32} \mathrm{~S}$ values (-8.5\%) of

159 pyrites within the columns as evidence for sulfur-respiring microorganism and the extremely

160 depleted $\delta^{13} \mathrm{C}$ values (between $-55.4 \%$ and $-43.3 \%$ ) of the organic laminae as evidence for

161 methanotrophic metabolism. Although the Moodies Group structures are morphologically similar

162 those described by Rasmussen et al. (2009), Moodies coelobionts lack cavity-associated sulfide

163 minerals and the $\delta^{13} \mathrm{C}$ values of the kerogen (between $-32.3 \%$ and $-21.3 \%$ ) are not indicative of an

164 ecosystem dominated by methanotrophs. Beyond excluding a methanotrophic metabolism of the

165 coelobionts, the isotopic data and the observed microfossils are consistent with both, a purely

166 chemotrophic or a photosynthetic community (House et al., 2000; Williford et al., 2013); the latter

167 being the dominant metabolism of the surficial mats located a few millimeters above the cavities

168 (Homann et al., 2015). In conclusion, the here reported data not only records the oldest evidence 
169 for cavity-dwelling life on Earth, but can also serve as an analog for UV-protected extraterrestrial

170 habitats e.g. on Mars.

171

172

173 ACKNOWLEDGMENTS

174 Research was supported by DFG grant He2418/13-1. We thank Anne-Sophie Bouvier and Lukas

175 Baumgartner for hosting and helping us at the Swiss SIMS facility, University of Lausanne,

176 Switzerland. Uwe Wiechert (FU Berlin) and Ulrich Struck (MfN Berlin) are thanked for bulk

177 isotope analysis.

178

179

180

181

\section{REFERENCES CITED}

182

183

184

185

186

187

188

189

190

191

192

193

194

195
Altermann, W., and Kazmierczak, J., 2003, Archean microfossils: A reappraisal of early life on Earth: Research in Microbiology, v. 154, no. 9, p. 611-617, doi: 10.1016/j.resmic.2003.08.006.

Anhaeusser, C.R., 1976, The geology of the Sheba Hills area of the Barberton Mountain Land, South Africa: with particular reference to the Eureka Syncline: Trans. Geol. Soc. S. Afr, v. 79, p. 253-280.

Bartley, J.K., 1996, Actualistic taphonomy of cyanobacteria: implications for the Precambrian fossil record: Palaios, v. 11, no. 6, p. 571-586, doi: 10.2307/3515192.

Bontognali, T.R.R., Sessions, a. L., Allwood, a. C., Fischer, W.W., Grotzinger, J.P., Summons, R.E., and Eiler, J.M., 2012, From the Cover: Sulfur isotopes of organic matter preserved in 3.45-billion-year-old stromatolites reveal microbial metabolism: Proceedings of the National Academy of Sciences, v. 109, no. 38, p. 15146-15151, doi: 10.1073/pnas.1207491109.

Boone, D.R., Castenholz, R.W., and Garrity, G.M. (Eds.), 2001, Bergey's Manual of Systematic Bacteriology: Springer, New York. 
196

197

198

199

200

201

202

203

204

205

206

207

208

209

210

211

212

213

214

215

216

217

218

219

220

221

222

223

224

225

226

227

228

229

Brasier, M., McLoughlin, N., Green, O., and Wacey, D., 2006, A fresh look at the fossil evidence for early Archaean cellular life: Philosophical transactions of the Royal Society of London. Series B, Biological sciences, v. 361, no. 1470, p. 887-902, doi: 10.1098/rstb.2006.1835.

Cockell, C.S., 1998, Biological effects of high ultraviolet radiation on early earth--a theoretical evaluation.: Journal of theoretical biology, v. 193, no. 4, p. 717-729, doi: 10.1006/jtbi.1998.0738.

Cockell, C.S., 2000, Ultraviolet radiation and the photobiology of earth's early oceans: Origins of Life and Evolution of the Biosphere, v. 30, no. 5, p. 467-499, doi: 10.1023/A:1006765405786.

Cockell, C.S., and Raven, J. a, 2007, Ozone and life on the Archaean Earth.: Philosophical transactions. Series A, Mathematical, physical, and engineering sciences, v. 365, no. 1856, p. 1889-1901, doi: 10.1098/rsta.2007.2049.

Eriksson, K.A., 1978, Alluvial and destructive beach facies from the Archaean Moodies Group, Barberton Mountain Land, South Africa and Swaziland, in Miall, A.D. ed., Fluvial Sedimentology, Can. Soc. Petrol. Geol., Mem. 5, p. 287-311.

Eriksson, K.A., 1979, Marginal marine depositional processes from the Archaean Moodies Group, Barberton Mountain Land; South Africa: Evidence and significance: Precambrian research, v. 8, p. 153-182.

Garcia-Pichel, F., and Bebout, B.M., 1996, Penetration of ultraviolet radiation into shallow water sediments: High exposure for photosynthetic communities: Marine Ecology Progress Series, v. 131 , no. 1-3, p. 257-262, doi: 10.3354/meps131257.

Gerdes, G., Klenke, T., and Noffke, N., 2000, Microbial signatures in peritidal siliciclastic sediments: a catalogue: Sedimentology, v. 47, p. 279-308.

Grossman, E.L., 2012, Oxygen Isotope Stratigraphy, in Gradstein, F.M., Ogg, J.G., Schmitz, M., and Ogg, G. eds., The Geologic Time Scale 2012, Elsevier, p. 181-206.

Grotzinger, J.P., and Reed, J.F., 1983, Evidence for primary aragonite precipitation, lower Proterozoic (1.9 Ga) Rocknest dolomite, Wopmay orogen, northwest Canada.: Geology, v. 11, no. 12, p. 710-713, doi: 10.1130/0091-7613(1983)11<710:EFPAPL>2.0.CO.

Heubeck, C., 2009, An early ecosystem of Archean tidal microbial mats (Moodies Group, South Africa, ca. 3.2 Ga): Geology, v. 37, no. 10, p. 931-934, doi: 10.1130/G30101A.1.

Heubeck, C., Engelhardt, J., Byerly, G.R., Zeh, A., Sell, B., Luber, T., and Lowe, D.R., 2013, Timing of deposition and deformation of the Moodies Group (Barberton Greenstone Belt, South Africa): Very-high-resolution of Archaean surface processes: Precambrian Research, v. 231, p. 236-262, doi: 10.1016/j.precamres.2013.03.021. 
Heubeck, C., and Lowe, D.R., 1994, Depositional and tectonic setting of the Archean Moodies Group, Barberton greenstone belt, South Africa: Precambrian research, v. 68, p. 257-290.

Heubeck, C., and Lowe, D.R., 1999, Sedimentary petrography and provenance of the Archean Moodies Grou, Barberton Greenstone Belt, in Lowe, D.R. and Byerly, G.R. eds., Geologic evolution of the Barberton Greenstone Belt, South Africa, Geological Society of America Special Paper 329, p. 259-286.

Homann, M., Heubeck, C., Airo, A., and Tice, M.M., 2015, Morphological adaptations of 3.22 Ga-old tufted microbial mats to Archean coastal habitats (Moodies Group, Barberton Greenstone Belt, South Africa): Precambrian Research, v. 266, p. 47-64, doi: 10.1016/j.precamres.2015.04.018.

Horodyski, R.J., and Knauth, L.P., 1994, Life on land in the precambrian.: Science (New York, N.Y.), v. 263, no. 5146, p. 494-498, doi: 10.1126/science.263.5146.494.

House, C.H., Schopf, J.W., McKeegan, K.D., Coath, C.D., Harrison, T.M., and Stetter, K.O., 2000, Carbon isotopic compostion of individual Precambrian microfossils: Geology, v. 28, no. 8 , p. $707-717$.

Jackson, T. a., 2014, Ultraviolet Radiation-Absorbing "Humic Pigments" of Cyanobacteria in Microbial Mats: Their Presumptive Photoprotective Function and Relevance to Early Precambrian Microbial Ecology and Evolution: Geomicrobiology Journal, v. 32, no. 5, p. 420-432, doi: 10.1080/01490451.2014.942445.

Jakubowicz, M., Berkowski, B., and Belka, Z., 2014, Cryptic coral-crinoid "hanging gardens" from the Middle Devonian of southern Morocco: Geology, v. 42, no. 2, p. 119-122, doi: 10.1130/G35217.1.

Jones, B., Renaut, R.W., and Konhauser, K.O., 2005, Genesis of large siliceous stromatolites at Frying Pan Lake, Waimangu geothermal field, North Island, New Zealand: Sedimentology, v. 52, no. 6, p. 1229-1252, doi: 10.1111/j.1365-3091.2005.00739.x.

Kobluk, D.R., and James, N.P., 1979, Cavity-dwelling organisms in Lower Cambrian patch reefs from southern Labrador: Lethaia, v. 12, p. 193-218, doi: 10.1111/j.15023931.1979.tb00997.x.

Léveillé, R.J., Fyfe, W.S., and Longstaffe, F.J., 2000, Geomicrobiology of carbonate-silicate microbialites from Hawaiian basaltic sea caves: Chemical Geology, v. 169, no. 3-4, p. 339355, doi: 10.1016/S0009-2541(00)00213-8.

Nisbet, E.G., and Sleep, N.H., 2001, The habitat and nature of early life.: Nature, v. 409, no. 6823, p. 1083-1091, doi: 10.1038/35059210.

Noffke, N., 2010, Microbial Mats in Sandy Deposits from the Archean to Today: Springer, Heidelberg. 
Noffke, N., Eriksson, K.A., Hazen, R.M., and Simpson, E.L., 2006, A new window into Early Archean life: Microbial mats in Earth's oldest siliciclastic tidal deposits (3.2 Ga Moodies Group, South Africa): Geology, v. 34, no. 4, p. 253, doi: 10.1130/G22246.1.

Olivier, N., Hantzpergue, P., Gaillard, C., Pittet, B., Leinfelder, R.R., Schmid, D.U., and Werner, W., 2003, Microbialite morphology, structure and growth: A model of the Upper Jurassic reefs of the Chay Peninsula (Western France): Palaeogeography, Palaeoclimatology, Palaeoecology, v. 193, no. 3-4, p. 383-404, doi: 10.1016/S0031-0182(03)00236-0.

Phoenix, V.R., Bennett, P.C., Engel, a. S., Tyler, S.W., and Ferris, F.G., 2006, Chilean highaltitude hot-spring sinters: A model system for UV screening mechanisms by early Precambrian cyanobacteria: Geobiology, v. 4, no. 1, p. 15-28, doi: 10.1111/j.14724669.2006.00063.x.

Phoenix, V.R., Konhauser, K.O., Adams, D.G., and Bottrell, S.H., 2001, Role of biomineralization as an ultraviolet shield: Implications for Archean life: Geology, v. 29, no. 9, p. 823-826, doi: 10.1130/0091-7613(2001)029<0823:ROBAAU>2.0.CO.

Rasmussen, B., Blake, T.S., Fletcher, I.R., and Kilburn, M.R., 2009, Evidence for microbial life in synsedimentary cavities from 2.75 Ga terrestrial environments: Geology, v. 37, no. 5, p. 423-426, doi: 10.1130/G25300A.1.

Riding, R., 2008, Abiogenic, microbial and hybrid authigenic carbonate crusts: components of Precambrian stromatolites: Geologia Croatica, v. 61, no. 2-3, p. 73-103, doi: 10.4154/GC.2008.10.

Schidlowski, M., Eichmann, R., and Junge, C.E., 1975, Precambrian sedimentary carbonates: carbon and oxygen isotope geochemistry and implications for the terrestrial oxygen budget: Precambrian Research, v. 2, no. 1, p. 1-69, doi: 10.1016/0301-9268(75)90018-2.

Schieber, J., Bose, P.K., and Eriksson, P.G., 2007, Atlas of microbial mat features preserved within the siliciclastic rock record (J. Schieber, P. K. Bose, P. . Eriksson, S. Banerjee, S. Sarkar, W. Altermann, \& O. Catuneanu, Eds.): Elsevier, Amsterdam.

Schopf, J.W., 2006, Fossil evidence of Archaean life.: Philosophical transactions of the Royal Society of London. Series B, Biological sciences, v. 361, no. 1470, p. 869-85, doi: 10.1098/rstb.2006.1834.

Schopf, J.W., 2004, Geochemical and submicron-scale morphologic analyses of individual Precambrian microorganisms: The Geochemical Society Special Publications, , no. 9, p. $365-375$.

Schopf, J.W., 2011, The paleobiological record of photosynthesis: Photosynthesis Research, v. 107, p. 87-101, doi: 10.1007/s11120-010-9577-1.

Shields, G., and Veizer, J., 2002, Precambrian marine carbonate isotope database: Version 1.1: Geochemistry, Geophysics, Geosystems, v. 3, no. 6, p. 1-12, doi: 10.1029/2001GC000266. 
Sugitani, K., Mimura, K., Nagaoka, T., Lepot, K., and Takeuchi, M., 2013, Microfossil assemblage from the 3400Ma Strelley Pool Formation in the Pilbara Craton, Western Australia: Results form a new locality: Precambrian Research, v. 226, p. 59-74, doi: 10.1016/j.precamres.2012.11.005.

Toulkeridis, T., Goldstein, S.L., Clauer, N., Kröner, A., Todt, W., and Schidlowski, M., 1998, $\mathrm{Sm}-\mathrm{Nd}, \mathrm{Rb}-\mathrm{Sr}$ and $\mathrm{Pb}-\mathrm{Pb}$ dating of silicic carbonates from the early Archaean Barberton Greenstone Belt, South Africa: evidence for post-depositional isotopic resetting at low temperature: Precambrian research, v. 92, p. 129-144.

Walker, J.J., and Pace, N.R., 2007, Endolithic Microbial Ecosystems: Annual Reviews in Microbiology, v. 61, p. 331-347, doi: 10.1146/annurev.micro.61.080706.093302.

Walker, J.J., Spear, J.R., and Pace, N.R., 2005, Geobiology of a microbial endolithic community in the Yellowstone geothermal environment.: Nature, v. 434, no. 7036, p. 1011-1014, doi: 10.1038 /nature 03447 .

Westall, F., Vries, D., Sjoukje, T., Nijman, W., Rouchon, V., Orberger, B., Pearson, V.K., Watson, J.S., Verchovsky, S., Wright, I., Rouzaud, J.-N., Marchesini, D., and Severine, A., 2006, The 3.466 Ga "Kitty's Gap Chert," an early Archean microbial ecosystem: v. 80301, no. 303, p. 105-131, doi: 10.1130/2006.2405(07).

Williford, K.H., Ushikubo, T., Schopf, J.W., Lepot, K., Kitajima, K., and Valley, J.W., 2013, Preservation and detection of microstructural and taxonomic correlations in the carbon isotopic compositions of individual Precambrian microfossils: Geochimica et Cosmochimica Acta, v. 104, p. 165-182, doi: 10.1016/j.gca.2012.11.005. 

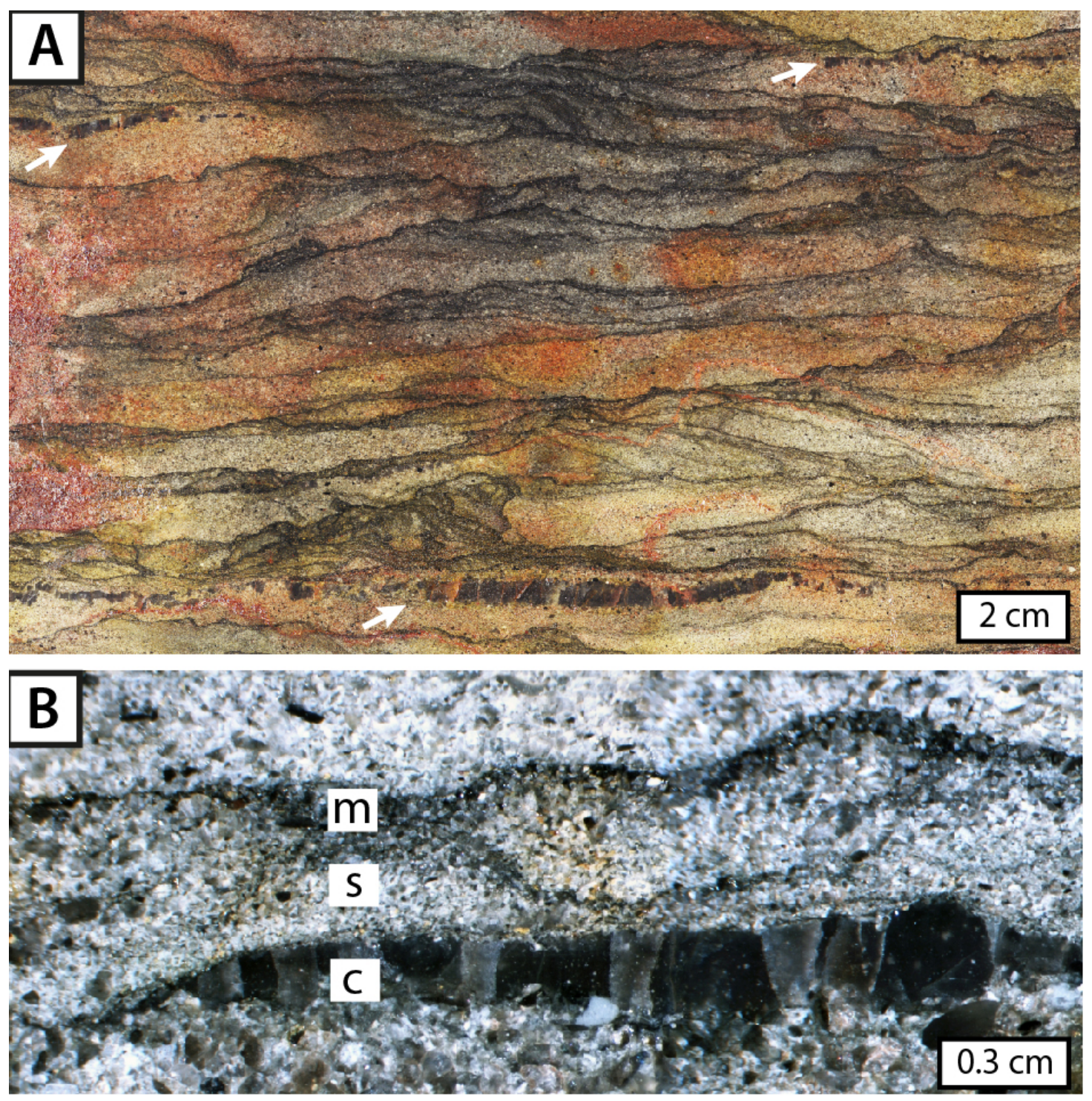

335 Figure 1. Polished slab photographs of microbial mats (dark laminae) of the Moodies Group

336 associated with chert-filled cavities. A: Lens-shaped, bedding-parallel cavities beneath the mats

337 (arrows). B: Detail view of lateral tapering cavity (c), which contains abundant kerogenous

338 microstructures and occurs below a thin layer of microbially-bound sediment (s) that is overlain by

339 a fossil mat (m). 

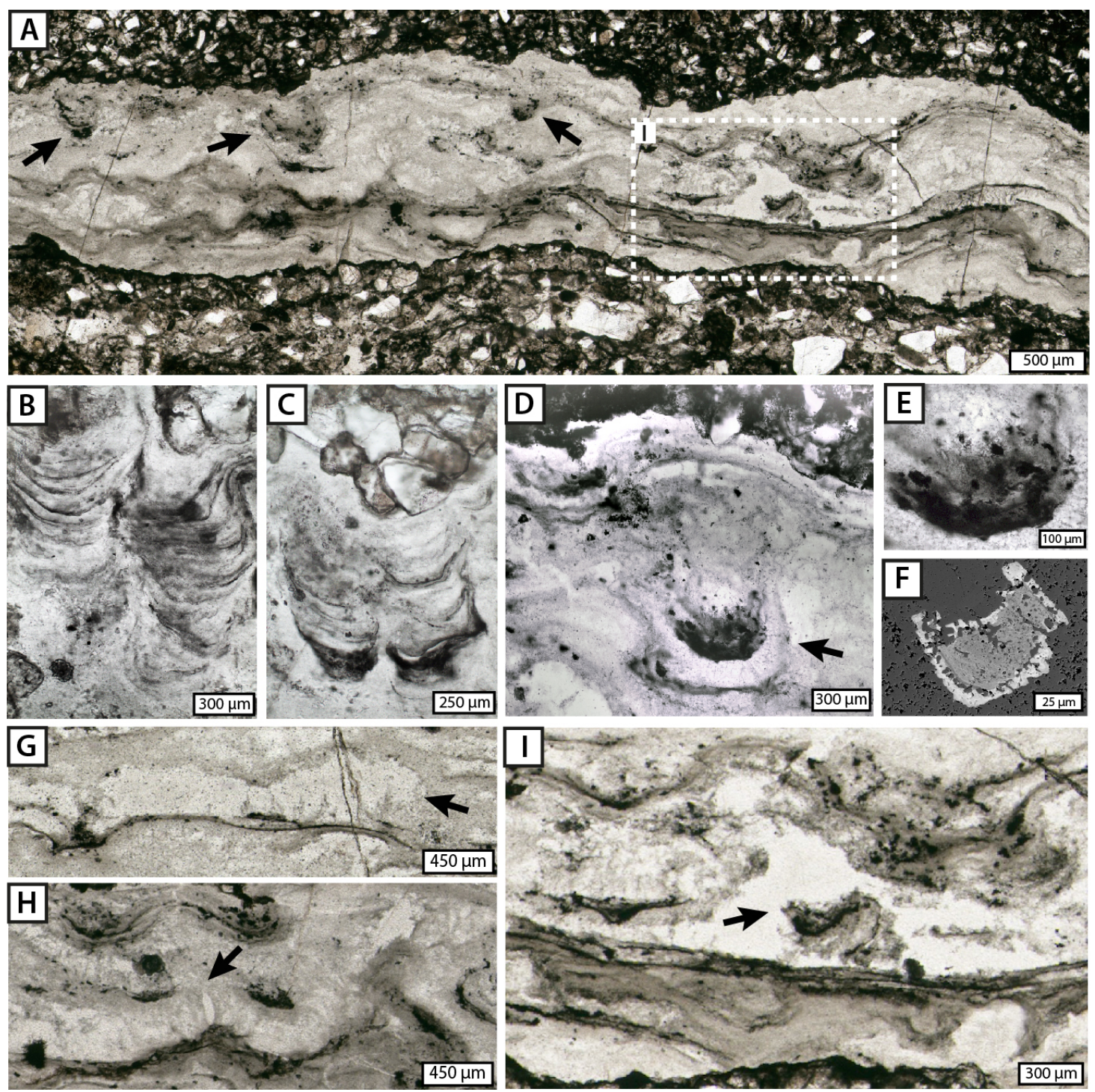

343 Figure 2. Transmitted light photomicrographs of downward accretionary kerogenous laminae

344 occurring within silicified cavities. A: Laminae with pendant protrusions (arrows) coating the

345 cavity ceiling. B, C: Downward-facing columnar microstromatolites attached to the cavity ceilings

346 with preserved kerogenous laminae. D: Pendant column with abundant dolomite remnants at the

347 tip encased by a cement crust (arrow). E: Close-up of the column tip in D showing dispersed

348 dolomite remnants. F: Backscatter electron photomicrograph of rhombic dolomite. G: Silicified

349 cement crust of botryoidal shape (arrow). H: Alternation of laminae and cement crusts containing

350 acicular crystal ghosts (arrow). Note that the lower lamina is disrupted and bent upwards. I: Close-

351 up of inset in A showing a detached and slightly deformed lamina fragment (arrow). 

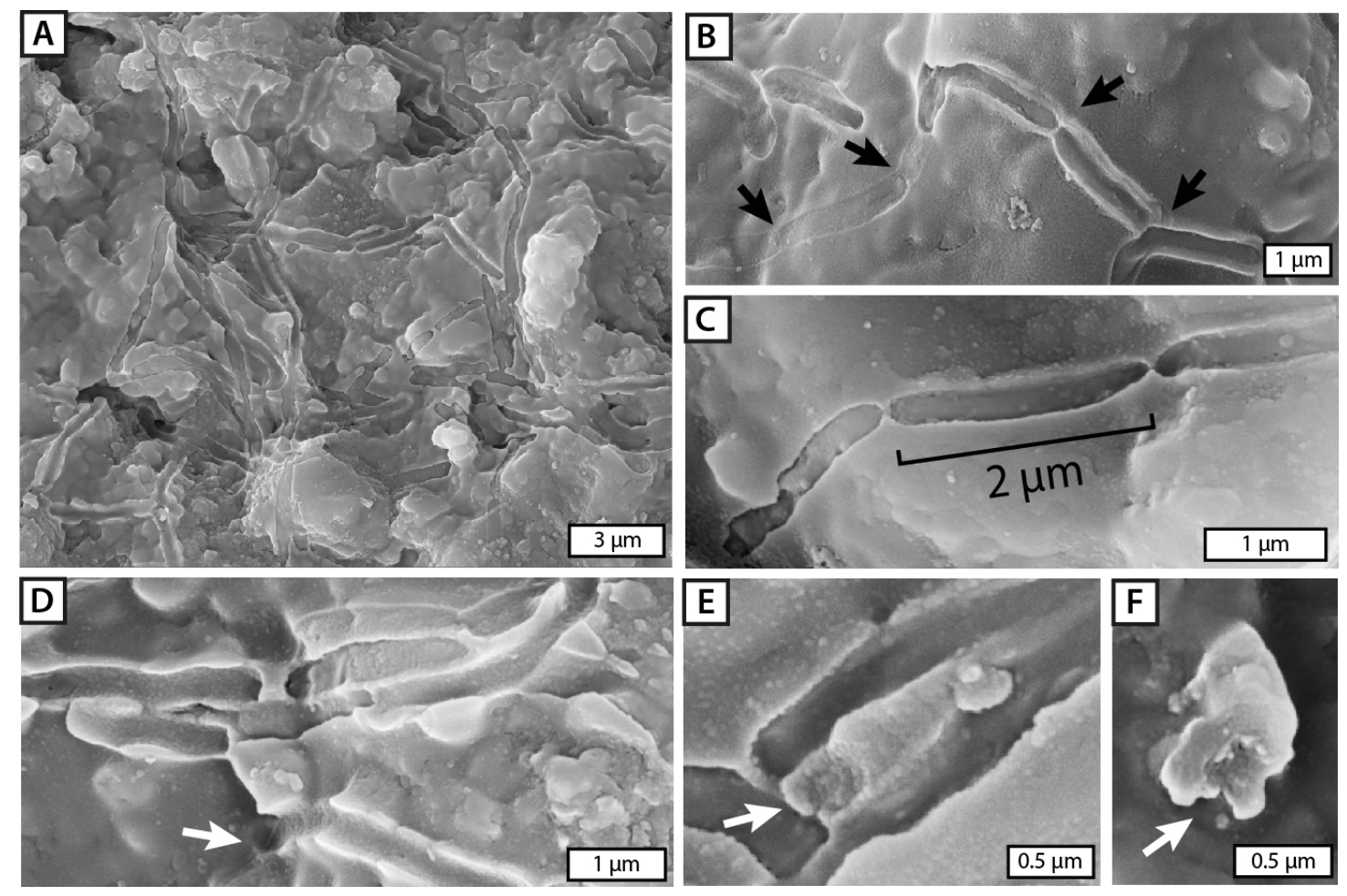

355 Figure 3. Secondary electron photomicrographs of filamentous microstructures permineralized by

356 chert. A: Meshwork of filament molds embedded in chert. B, C: Filamentous molds subdivided in

357 regularly-spaced, rod-shaped segments (arrows) of similar length. D, E, F: Cell-molds in transverse

358 cross-section showing a tubular morphology encased by silica (arrows). 

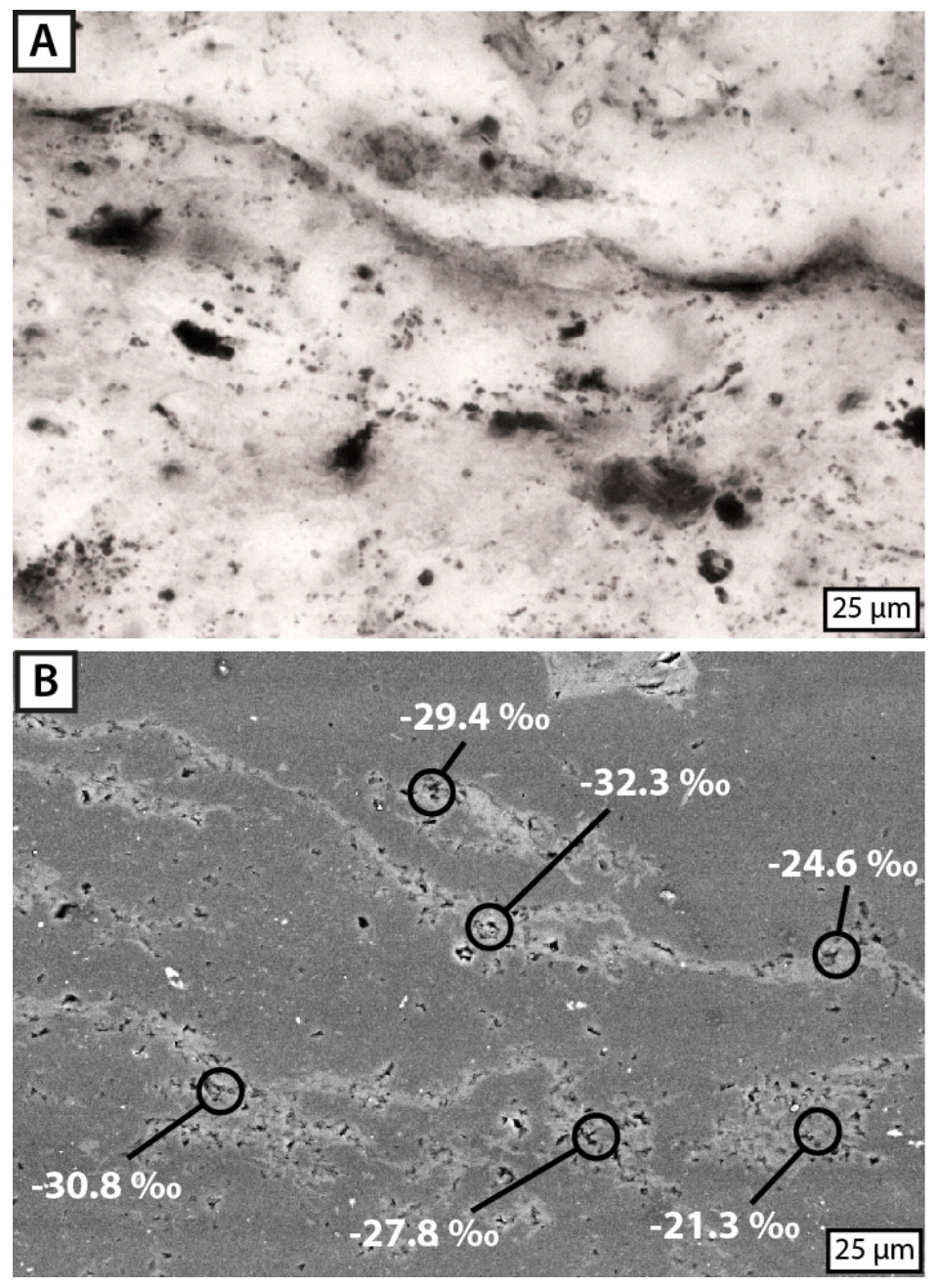

366 Figure. 4 A: Thin section photomicrograph displaying kerogenous lamina. B: Backscatter electron

367 photomicrograph of A with SIMS analytical areas and corresponding $\delta^{13} \mathrm{C}_{\mathrm{PDB}}$ values. 
$387{ }^{1}$ GSA Data Repository item 2015xxx, Figures DR1-DR4 (sample locality, Raman spectroscopy, 388 filament size distribution) and Table DR1 (SIMS isotope data), is available online at 389 www.geosociety.org/pubs/xxx.htm, or on request from editing@geosociety.org or Documents 390 Secretary, GSA, P.O. Box 9140, Boulder, CO 80301, USA. 